\title{
PENGEMBANGAN MODUL PEMBELAJARAN MEKANIKA TEKNIK UNTUK SMK KELAS X KOMPETENSI KEAHLIAN DESAIN PERMODELAN DAN INFORMASI BANGUNAN
}

\author{
Yohan Adi Putra $^{1}$ dan V. Lilik Hariyanto ${ }^{2}$ \\ ${ }^{1,2}$ Pendidikan Teknik Sipil dan Perencanaan, FT, UNY \\ Email: yohanadiputra.yap@gmail.com
}

\begin{abstract}
ABSTRAK
Pada kegiatan pembelajaran, penggunaan modul merupakan salah satu langkah untuk meningkatkan kualitas pembelajaran pada siswa. Penelitian ini memiliki tujuan mengembangkan media pembelajaran modul Mekanika Teknik untuk kelas X SMK kompetensi keahlian Desain Permodelan dan Informasi Bangunan. Penelitian ini merupakan penelitian Research and Development (R\&D) dengan model penelitian pengembangan siklus 4D (Define, Design, Development and Disseminate). Metode pengumpulan data yang digunakan adalah angket. Angket meliputi angket penilaian kelayakan media, angket penilaian kelayakan materi, angket penilaian kelayakan menurut guru mekanika teknik, dan angket penilaian proses pengembangan. Teknik analisis data yang digunakan adalah analisis statistik deskriptif. Hasil penelitian menunjukkan bahwa: (1) Tahap define dilaksanakan dengan sangat baik didapatkan skor 40 berada pada rentang 37,8 $<\mathrm{X}$ dan nilai konversi skala 100 sebesar 86,11; (2) Tahap design dilaksanakan dengan sangat baik didapatkan skor maksimal 20 berada pada rentang 16,8 $<\mathrm{X}$ dan nilai konversi sebesar 100; (3) Tahap development dilaksanakan dengan sangat baik didapatkan skor 19 berada pada rentang 16,8 < X dan nilai konversi sebesar 93,75. Hasil validasi adalah sebagai berikut: a) ahli media menyatakan modul "sangat layak" dengan skor 222 berada pada rentang 197,4<X dan nilai konversi sebesar 93,085, b) ahli materi menyatakan modul "layak" dengan skor 163 berada pada rentang $142,8<X<176,4$ dan nilai konversi sebesar 72,023, c) guru menyatakan modul "sangat layak" dengan skor 207 berada pada rentang $176,4<\mathrm{X}$ dan nilai konversi sebesar 98,21; (4) Tahap disseminate dilaksanakan dengan sangat baik didapatkan skor 5 berada pada rentang 4,2<X dan nilai konversi sebesar 100 .
\end{abstract}

Kata kunci: Penelitian \& Pengembangan, Modul, Mekanika Teknik

\begin{abstract}
In the learning activities, the use of modules is one step to improve the quality of learning in students. The aim of this research is to develop an engineering mechanics learning module for X graded Vocational High School of design building information and modeling's. This is a research development (R\&D) with a $4 D$ (Define, Design, Development and Disseminate) cycle development research model. The data was collected using questionaires. The questionnaire includes a media feasibility assessment, a material feasibility assessment, a teacher feasibility assessment, and a development process success assessment. The data was analysed using descriptive statistic method. The results of the research shows: (1) The define stage has done very well. This stage gets a score of 40, the score is in the range of $37.8<X$ and a conversion value of 100's scale is 86.11; (2) The design stage has done very well. This stage gets a maximum score of 20, the score is in the range of $16.8<X$ and a conversion value is 100; (3) The development stage has done very well. This stage gets a score of 19, the score is in the range of 16.8 $<X$ and a conversion value is 93.75. The validation results shows: a) media experts stated that the module was "very feasible". The assessment gets a score of 222. The score is in the range of $197.4<X$ and a conversion value is 93.085, b) material experts stated that the module was "feasible" the assessment gets a score of 163. The score is in the range of $142.8<X<176.4$ and a conversion value is $72.023, c)$ The teacher stated that the module was "very feasible". The assessment gets a score of 207. The score is in the range of $176.4<X$ and a conversion value is 98.21. (4) The disseminate stage has done very well. This stage gets a score of 5. The score is in the range 4.2 $<X$ and a conversion value is 100 .
\end{abstract}

Keywords: Research \& Development, Module, Engineering Mechanics 


\section{PENDAHULUAN}

Pendidikan menjadi suatu hal yang sangat penting bagi kehidupan suatu bangsa dimana hal tersebut menentukan kecerdasan bangsa untuk mempertahankan kemerdekaan. Sistem pendidikan yang berjalan sangat menentukan baik buruknya perkembangan mutu pendidikan tersebut. Potensi manusia perlu dikembangkan melalui pendidikan. Seiring berkembangnya zaman, sistem pendidikan juga mengalami perkembangan sangat pesat pula. Hal tersebut dapat dilihat dari bentuk kurikulum yang sering berubah-ubah setiap beberapa periode dan terus diperbarui. Perubahan kurikulum disesuaikan dengan perubahan pola pikir dan kondisi manusia yang semakin berkembang maju pula. Dengan adanya hal tersebut, setiap manusia diharuskan turut serta dalam mengikuti perubahan suatu sistem pendidikan tersebut agar tidak tergerus oleh modernisasi dan perkembangan zaman era globalisasi pada saat ini. Oleh karena itu, suatu sistem pendidikan yang memadai sangat diperlukan.

Sekolah merupakan salah satu tempat untuk kegiatan belajar mengajar sangat mungkin menjadi tempat yang terkena dampak dari perubahan sistem dan konsep pendidikan yang selalu berubah-ubah. Hal ini membuat pihak sekolah harus pandaipandai dalam menyikapi hal tersebut. Walaupun dalam kenyataannya terkadang pihak sekolah tidak bisa seketika untuk menerima perubahan iklim pendidikan tersebut, namun tuntutan tersebut tidak dapat terhindar darinya. Pengambilan keputusan dapat mempengaruhi sistem pembelajaran di dalam lingkup sekolah tersebut terutama dalam suasana kelas.
Sekolah yang turut andil dalam perkembangan pendidikan berarti juga turut berperan dalam perkembangan pendidikan yang semakin berkembang maju. Sekolah diharuskan mampu untuk memenuhi kebutuhan yang sekiranya diperlukan dalam pembelajaran baik dalam bentuk fisik dan non-fisik. Kebutuhan-kebutuhan pembelajaran yang dimaksud adalah berupa barang maupun jasa. Contoh kebutuhan yang bersifat fisik antara lain adalah berupa gedung sekolah yang memadai, runga kelas yang nyaman dan layak untuk digunakan disertai dengan fasilitas-fasilitas yang menunjang pembelajaran, Contoh kebutuhan non-fisik antara lain adalah keterampilan pendidik serta kompetensi yang dimiliki oleh pendidik dalam proses mengajarnya di kelas.

Sekolah yang sangat diharapkan dalam perkembangannya salah satunya adalah Sekolah Menengah Kejuruan (SMK). Sekolah Menengah Kejuruan adalah salah satu dari pendidikan formal yang ada di Indonesia dimana tujuan dari sekolah tersebut adalah mendidik dan mencetak peserta didik yang dapat memiliki keahlian di bidangnya masing-masing. Keahlian yang diajarkan dalam Sekolah Menengah Kejuruan diharapkan dapat digunakan untuk dunia industri dan dunia usaha ketika peserta didik sudah lulus. Namun seiring berjalannya waktu bahan yang diajarkan dalam Sekolah Menengah Kejuruan tidak bisa mengikuti kemajuan perkembangan teknologi yang pesat. Pada akhirnya keahlian yang dibutuhkan oleh dunia industri maupun dunia usaha tidak seperti keahlian lulusan Sekolah Menengah Kejuruan saat ini.

Menurut kepala Badan Pusat Statistik (BPS) Suharyanto yang dikutip oleh Fajar Pebrianto (28/08/2020) dalam Tempo.co 
menyatakan bahwa Tingkat Pengangguran Terbuka (TPT) di Indonesia per Februari 2020 berjumlah 6,88 juta atau sekitar 4,99 $\%$. Angka ini menurun sekitar $0,02 \%$ dibandingkan dengan prosentase per Februari 2019 persentasenya adalah sekitar $5,01 \%$. Meskipun seperti itu jumlah pengangguran dari tamatan Sekolah Menengah Kejuruan menempati jumlah pengangguran paling tinggi diantara tamatan pendidikan lain. Persentase pengangguran dari tamatan Sekolah Menengah Kejuruan (SMK) sebesar 8,49\%, sedangkan persentase pengangguran dari tamatan Sekolah Dasar (SD) ke bawah sebesar 2,64\%, pengangguran tamatan Sekolah Menengah Pertama (SMP) sebesar 5,02\%, pengangguran tamatan Sekolah Menengah Atas (SMA) sebesar 6,77\%, pengangguran tamatan Diploma I/II/III sebesar 6,76\%, dan pengangguran tamatan Sarjana 5,73\%.

Ilmu pengetahuan dan teknologi sangat berperan dan sangat dibutuhkan dalam upaya peningkatan kompetensi siswa lulusan Sekolah Menengah Kejuruan (SMK). Lulusan Sekolah Menengah Kejuruan (SMK) diharapkan bisa mendapatkan pekerjaan pada dunia industri yang sesuai bidang yang dikuasainya, sehingga pengangguran terdidik lulusan Sekolah Menengah Kejuruan (SMK) dapat berkurang. Kemajuan ilmu pengetahuan dan teknologi menuntut manusia untuk padat memiliki pengetahuan dan informasi (Ariyanto Saputro, 2015:17). Penggunaan media sangat berhubungan dengan pengetahuan dan informasi. Media diklasifikasikan menjadi tujuh menurut bentuk dan cara penyajiannya yaitu, media proyeksi, media audio, berbentuk film, media audio visual, media berbentuk film, media televisi, media berbahan cetak, dan multimedia (Tejo Nurseto, 2011:23). Media komunikasi di dalam dunia pendidikan memiliki tujuan untuk sebagai suatu sarana dalam menyediakan informasi. Media pembelajaran merupakan salah satu sarana yang dipergunakan untuk menyampaikan sebuah pesan atau informasi kepada siswa dari suatu sumber belajar. Sarana atau alat bantu pendidikan dipergunakan sebagai perantara atau alat di dalam suatu proses pembelajaran untuk mencapai tujuan pengajaran secara efektif dan efisien (Hujair Sanaky, 2013:3).

Salah satu sekolah formal yang dijadikan sebagai sasaran penelitian dalam hal ini adalah SMK N 1 Sedayu. SMK N 1 Sedayu menunjukkan komitmennya untuk mencetak generasi yang unggul, terampil dan kreatif sehingga mampu bersaing dalam pemenuhan perkembangan teknologi. SMK N 1 Sedayu menggunakan Kurikulum 2013 revisi 2017. Sebelumnya dalam penerapan kurikulum yang baru masih dipadukan dengan kurikulum lama yaitu kurikulum 2006. Namun untuk sekarang ini penerapan Kurikulum 2013 telah diterapkan sepenuhnya.

Pada penerapannya Kurikulum 2013, siswa dituntut untuk turut aktif di dalam proses kegiatan pembelajaran, sehingga diharapkan siswa akan tumbuh sikap kreatif dan inovatif dalam pemecahan setiap masalah yang siswa hadapi di sekolah. Kurikulum 2013 revisi juga memfokuskan pada pendidikan karakter serta pendidikan budi pekerti yang diintegrasikan ke dalam program studi sehingga tidak hanya keterampilan dan pengetahuan saja yang dimiliki oleh siswa namun juga kecerdasan sikap. Guru hanya berperan menjadi fasilitator sehingga keatifitas guru juga sangat diperlukan agar proses pembelajaran tetap berjalan dengan baik. Sarana dan prasarana juga harus mendukung proses 
pembelajaran. Siswa dalam aktifitas pembelajaran perlu difasilitasi dengan apapun yang mendukung proses pembelajaran dalam rangka pemenuhan materi pembelajaran.

Mekanika Teknik adalah salah satu mata pelajaran yang sangat penting khususnya dalam jurusan Desain Permodelan dan Informasi Bangunan (DPIB) di Sekolah Menengah Kejuruan Negeri 1 Sedayu. Mekanika Teknik menjadi sorotan yang memiliki porsi perhatian tersendiri dari kalangan pendidik maupun peserta didik. Dalam mata pelajaran Mekanika Teknik ini siswa dituntut untuk memahami mengenai hal-hal yang memiliki keterkaitan dengan struktur seperti elemen, faktor yang mempengaruhi struktur, pembebanan, gaya-gaya dalam struktur sehingga siswa dapat menganalisis dan memperhitungkan apa saja yang berkaitan dengan struktur. Namun masih banyak sekali dijumpai beberapa siswa di SMK N 1 Sedayu yang tidak mampu memahami materi pelajaran Mekanika Teknik ini. Kemampuan mereka masih terbilang kurang ditinjau dari hasil tugas dan ujian mereka yang mendapatkan hasil nilai di bawah ratarata. Mekanika Teknik merupakan mata pelajaran yang komplek dan abstrak sehingga perlu adanya perhatian khusus dari siswa. Kesadaran siswa dalam mempelajari mata pelajaran ini secara maksimal harus ditingkatkan. Kesadaran untuk belajar secara mandiri sangat mempengaruhi keberhasilan dalam memahami mata pelajaran Mekanika Teknik.

Setelah melaksanakan kegiatan observasi dalam proses pembelajaran Mekanika Teknik di SMK N 1 Sedayu, peneliti menemukan beberapa permasalahan dalam proses pembelajaran Mekanika Teknik. Permasalahan-permasalahan yang muncul dalam pembelajaran Mekanika Teknik dapat menyebabkan kompetensi siswa menjadi rendah serta kesulitan dalam memahami pelajaran ini. Ketidakmampuan guru dalam menghasilkan pembelajaran yang baik akan menyebabkan tidak tercapainya kompetensi siswa. Penggunaan metode pembelajaran presentasi dan teacher center learning tanpa memberikan umpan balik pada siswa dirasa kurang sesuai dan tidak menarik minat siswa. Hal tersebut dapat membuat siswa menjadi cepat merasa bosan dilihat dari perilaku siswa yang tidak memperhatikan penjelasan guru dan melakukan aktivitas lain seperti bercerita dengan teman dan tidur menunduk. Guru mata pelajaran Mekanika Teknik kurang berinisiatif dalam menyajikan sumber belajar berupa media pembelajaran. Ketersediaan sumber belajar berupa media pembelajaran modul Mekanika Teknik di dalam perpustakaan milik SMK N 1 Sedayu yang masih tidak sesuai dengan Kurikulum 2013 revisi sehingga mempengaruhi kualitas pembelajaran dalam mencapai kompetensi dasar. Referensi belajar Mekanika Teknik yang dipakai di jurusan DPIB di SMK N 1 Sedayu saat ini masih mengacu pada buku lama. Bahkan sering dijumpai guru meminjam buku dari jurusan Teknik Permesinan karena adanya sedikit persamaan materi ajar. Penyusunan materi yang akan diajarkan disusun berdasarkan pengetahuan materi yang diketahui oleh guru mata pelajaran Mekanika Teknik.

Berdasarkan permasalahkan yang telah diuraikan tersebut, maka perlu adanya penelitian yang dapat dijadikan sebagai solusi dalam mengatasi masalah tersebut. Penelitian yang dirasa sesuai adalah penelitian pengembangan atau Research and Development (R\&D). Penelitian tersebut memiliki tujuan untuk mengembangan 
media yang layak untuk digunakan dalam proses pembelajaran. Media yang dipilih oleh penulis untuk dikembangkan adalah media pembelajaran modul.

Modul didefinisikan sebagai salah satu bentuk dari bahan mengajar yang direncanakan untuk membantu siswa dalam upaya menguasai tujuan pembelajaran. Secara spesifik, di dalamnya terdapat seperangkat pengalaman pembelajaran yang direncanakan dengan cara sistematis, utuh dan terencana. (Daryanto, 2013:9). Penggunaan sumber belajar media pembelajaran modul sangat bermanfaat dalam upaya memudahkan interaksi guru dengan siswa, bahkan antara siswa dengan siswa. Media pembelajaran modul juga membuat siswa menjadi lebih mudah memperluas wawasan serta memperdalam pemahaman secara mandiri.

\section{METODE}

Penelitian ini digunakan jenis penelitian pengembangan atau Research and Development (R\&D). Penelitian Research and Development (R\&D) ini diformulasikan dengan metode penelitian pengembangan perangkat model siklus 4 tahapan pengembangan yang disebut 4D (Four-D). Menurut Thiagarajan, dkk (1974) pengembangan menggunakan 4D memiliki empat tahap pengembangan, yaitu : (1) Tahap pendefinisian (define), (2) Tahap perencanaan (design), (3) Tahap pengembangan (development), dan (4) tahapan desiminasi (disseminate).

Tahap define dikenal sebagai tahapan analisis kebutuhan. Tahap ini dilaksanakan kegiatan analisis kebutuhan serta syaratsyarat untuk mengembangkan produk. Tahap define memiliki lima kegiatan yaitu : (1) front-end analysis, (2) leaner analysis,
(3) task analysis, (4) concept analysis, dan

(5) specifiying instructional objectives. Data dari tahap define diperoleh dengan metode observasi. Tahap design memiliki tujuan untuk menghasilkan rancangan suatu produk yang dikembangkan. Tahap design terdapat empat kegiatan yaitu : (1) construction criterion referenced test, (2) media selection, (3) format selection, dan (4) initial design. Tahap development terbagi atas dua kegiatan pengembangan yaitu expert appraisal dan development testing. Tahap disseminate dilakukan dengan cara mensosialisasikan media pembelajaran. Dalam proses sosialisasi media pembelajaran dilakukan distribusi dalam jumlah yang ditentukan kepada pengguna dalam hal ini adalah guru dan siswa.

Objek dalam penelitian ini adalah Media Pembelajaran Modul Mekanika Teknik Kelas X Semester Gasal Desain Pemodelan dan Informasi Bangunan untuk SMK Negeri 1 Sedayu. Dalam penelitian ini melibatkan responden yang antara lain terdiri dari ahli penelitian pengembangan, ahli media, ahli materi, dan guru Mekanika Teknik. Responden untuk ahli penelitian pengembangan, ahli materi dan ahli media dilakukan dan diwakilkan oleh dosen sebagai seorang akademisi dan ahli dari Jurusan Pendidikan Teknik Sipil dan Perencanaan Universitas Negeri Yogyakarta yang memiliki kualifikasi, kompetensi dan pengalaman dalam bidang tersebut. Responden untuk mewakili subjek akan diwakili oleh guru pengampu mata pelajaran Mekanika Teknik kelas X Kompetensi Keahlian Desain Permodelan dan Informasi Bangunan SMK Negeri 1 Sedayu.

Metode pengumpulan data yang dipergunakan pada penelitian ini adalah menggunakan observasi dan menggunakan angket penilaian atau kuesioner. Observasi 
dilakukan dengan tujuan untuk mengamati dan mencari permasalah yang mendasar dalam proses pembelajaran hingga mencari tahu kebutuhan media pembelajaran untuk menunjang proses pembelajaran Mekanika Teknik. Observasi juga dimaksudkan untuk mencari dokumen-dokumen pendukung untuk pengembangan materi. Sedangkan untuk angket penilaian atau kuesioner dipergunakan guna menilai tingkat kelayakan dan memvalidasi media pembelajaran modul yang telah dibuat serta menilai sejauh mana tingkat keberhasilan dalam mengembangan sebuah produk terkait. Ada 4 angket yang digunakan dalam penelitian ini yaitu : (1) Angket proses pengembangan model 4D, (2) Angket validasi media, (3) Angket validasi materi, dan (4) Angket validasi guru. Berikut adalah kisi-kisi dari masing-masing angket yang digunakan :

Tabel 1. Kisi-Kisi Instrumen Penilaian Proses Pengembangan Media

\begin{tabular}{ll}
\hline \multicolumn{1}{c}{ Indikator } & \multicolumn{1}{c}{ Sub Indikator } \\
\hline Pendefinisian & Front and Analysis, Learner \\
& Analysis, Task Analysis, \\
& Concept Analysis, dan \\
& Specifying Instruksional \\
& Objectives. \\
Perencanaan & Construction Criterion \\
& Referenced Test, Media \\
& Selection, Format Selection, \\
& dan Initial Design. \\
Pengembangan & Validasi dan Uji Coba \\
Penyebaran & Penyebaran modul \\
\hline
\end{tabular}

Tabel 2. Kisis-Kisi Validasi Media

\begin{tabular}{ll}
\hline \multicolumn{1}{c}{ Aspek } & \multicolumn{1}{c}{ Indikator } \\
\hline Ukuran & $\begin{array}{l}\text { Ukuran modul sesuai } \\
\text { Standar ISO }\end{array}$ \\
& $\begin{array}{l}\text { Tata letak sampul, Tipografi } \\
\text { sampul, dan Ilustrasi kulit } \\
\text { Desain sampul } \\
\end{array}$ \\
& $\begin{array}{l}\text { Tatal letak isi, Tipografi isi } \\
\text { modul, dan Ilustrasi isi } \\
\text { modul }\end{array}$ \\
\hline
\end{tabular}

Tabel 3. Kisi-Kisi Instrumen Validasi Materi

\begin{tabular}{|c|c|}
\hline Indikator & Sub Indikator \\
\hline Cakupan Materi & $\begin{array}{l}\text { 1. Kesesuaian materi dengan } \\
\text { tujuan pembelajaran } \\
\text { 2. Kelengkapan, keluasan } \\
\text { dan kedalaman materi }\end{array}$ \\
\hline Ketepatan & 1. Ketepatan \\
\hline Materi & $\begin{array}{l}\text { fakta/lambang/simbol } \\
\text { 2. Ketepatan konsep/definisi } \\
\text { 3. Ketepatan Prinsip } \\
\text { (Teorema, Aksioma, } \\
\text { Dalil, Sifat, Aturan, } \\
\text { Hukum) } \\
\text { 4. Ketepatan Prosedur / } \\
\text { Algoritma } \\
\text { 5. Ketepatan contoh }\end{array}$ \\
\hline Evaluasi & $\begin{array}{l}\text { 1. Soal mengukur tujuan } \\
\text { pembelajaran } \\
\text { 2. Proporsi kompleksitas } \\
\text { berpikir ranah kognitif }\end{array}$ \\
\hline $\begin{array}{l}\text { Dimensi } \\
\text { Keterampilan }\end{array}$ & $\begin{array}{l}\text { 1. Cakupan Keterampilan } \\
\text { sesuai tujuan } \\
\text { pembelajaran } \\
\text { 2. Ketepatan dan keruntutan } \\
\text { kegiatan }\end{array}$ \\
\hline $\begin{array}{l}\text { Organisasi } \\
\text { Materi }\end{array}$ & $\begin{array}{ll}\text { 1. } & \text { Keruntutan Penyajian } \\
\text { Materi } \\
\text { 2. Kelogisan Penyajian } \\
\text { Materi } \\
\text { 3. Konsistensi Penyajian } \\
\text { Materi }\end{array}$ \\
\hline $\begin{array}{l}\text { Pendukung } \\
\text { Penyajian }\end{array}$ & $\begin{array}{l}\text { 1. Kesesuaian dan } \\
\text { Ketepatan ilustrasi }\end{array}$ \\
\hline Materi & $\begin{array}{l}\text { 2. Membangkitkan motivasi } \\
\text { belajar } \\
\text { 3. Rangkuman pada setiap } \\
\text { akhir kegiatan } \\
\text { pembelajaran } \\
\text { 4. Ketepatan penomoran dan } \\
\text { penamaan tabel, gambar, } \\
\text { dan lampiran }\end{array}$ \\
\hline $\begin{array}{l}\text { Kelengkapan } \\
\text { Penyajian }\end{array}$ & $\begin{array}{l}\text { 1. Petunjuk penggunaan } \\
\text { modul } \\
\text { 2. Daftar Isi } \\
\text { 3. Daftar Pustaka } \\
\text { 4. Peta Konsep } \\
\text { 5. Kunci Jawaban }\end{array}$ \\
\hline
\end{tabular}

Tabel 4. Kisi-Kisi Instrumen Validasi Guru

\begin{tabular}{cc}
\hline \multicolumn{1}{c}{ Indikator } & \multicolumn{1}{c}{ Sub Indikator } \\
\hline Cakupan Materi & $\begin{array}{l}\text { 1. Kesesuaian materi dengan } \\
\text { tujuan pembelajaran } \\
\text { 2. Kelengkapan, keluasan } \\
\text { dan kedalaman materi }\end{array}$ \\
\hline
\end{tabular}




\begin{tabular}{|c|c|}
\hline Indikator & Sub Indikator \\
\hline Ketepatan & 1. Ketepatan \\
\hline \multirow[t]{7}{*}{ Materi } & fakta/lambang/simbol \\
\hline & 2. Ketepatan konsep/definisi \\
\hline & 3. Ketepatan Prinsip \\
\hline & $\begin{array}{l}\text { (Teorema, Aksioma, Dalil, } \\
\text { Sifat, Aturan, Hukum) }\end{array}$ \\
\hline & 4. Ketepatan Prosedur / \\
\hline & Algoritma \\
\hline & 5. Ketepatan contoh \\
\hline \multirow[t]{2}{*}{ Evaluasi } & $\begin{array}{l}\text { 1. Soal mengukur tujuan } \\
\text { pembelajaran }\end{array}$ \\
\hline & $\begin{array}{l}\text { 2. Proporsi kompleksitas } \\
\text { berpikir ranah kognitif }\end{array}$ \\
\hline \multirow{3}{*}{$\begin{array}{l}\text { Dimensi } \\
\text { Keterampilan }\end{array}$} & 1. Cakupan Keterampilan \\
\hline & $\begin{array}{l}\text { sesuai tujuan } \\
\text { pembelajaran }\end{array}$ \\
\hline & $\begin{array}{l}\text { 2. Ketepatan dan keruntutan } \\
\text { kegiatan }\end{array}$ \\
\hline Organisasi & 1. Keruntutan Penyajian \\
\hline \multirow[t]{5}{*}{ Materi } & Materi \\
\hline & 2. Kelogisan Penyajian \\
\hline & Materi \\
\hline & 3. Konsistensi Penyajian \\
\hline & Materi \\
\hline \multirow{5}{*}{$\begin{array}{l}\text { Pendukung } \\
\text { Penyajian Materi }\end{array}$} & 1. Kesesuaian dan Ketepatan \\
\hline & ilustrasi \\
\hline & $\begin{array}{l}\text { 2. Membangkitkan motivasi } \\
\text { belajar }\end{array}$ \\
\hline & $\begin{array}{l}\text { 3. Rangkuman pada setiap } \\
\text { akhir kegiatan } \\
\text { pembelajaran }\end{array}$ \\
\hline & $\begin{array}{l}\text { 4. Ketepatan penomoran dan } \\
\text { penamaan tabel, gambar, } \\
\text { dan lampiran }\end{array}$ \\
\hline \multirow{6}{*}{$\begin{array}{l}\text { Kelengkapan } \\
\text { Penyajian }\end{array}$} & 1. Petunjuk penggunaan \\
\hline & modul \\
\hline & 2. Daftar Isi \\
\hline & 3. Daftar Pustaka \\
\hline & 4. Peta Konsep \\
\hline & 5. Kunci Jawaban \\
\hline
\end{tabular}

Teknik analisis data yang digunakan adalah teknik analisis statistik deskriptif. Analisis statistik deskriptif berarti memberikan deskripsi atau gambaran data yang telah dikumpulkan secara sistematik, faktual dan akurat terhadap permasalahan yang ada dalam penelitian. Menurut Sugiyono (2016:207-208) mengemukakan bahwa analisis deskriptif adalah statistika yang dipergunakan guna menganalisa data dengan cara memberikan deskrisi atau gambaran data yang telah dikumpulkan dengan apa adanya dan tidak dimaksudkan untuk memberikan simpulan yang berlaku untuk umum atau generalisasinya. Skala imterval yang digunakan pada penelitian ini menggunkan skala Likert.

Tabel 5. Skala Likert untuk Instrumen

\begin{tabular}{lc}
\hline \multicolumn{1}{c}{ Kategori } & Skor \\
\hline Sangat Layak (SL) & 5 \\
Layak (L) & 4 \\
Cukup Layak (CL) & 3 \\
Kurang Layak (KL) & 2 \\
Tidak Layak (TL) & 1 \\
\hline
\end{tabular}

Data yang didapatkan dari penilaian validasi berupa skor diubah menjadi data kualitatif berdasarkan data interval dengan dasar konversi.

Tabel 6. Interpretasi Kelayakan Validasi

\begin{tabular}{|c|c|}
\hline Interval Nilai & $\begin{array}{c}\text { Kategori } \\
\text { Kelayakan }\end{array}$ \\
\hline$\overline{\mathrm{Xi}+1,8 \mathrm{SBi}<\mathrm{X}}$ & Sangat Layak \\
\hline $\begin{array}{l}\mathrm{Xi}+0,6 \mathrm{SBi}<\mathrm{X} \leq \mathrm{Xi}+1,8 \\
\mathrm{SBi}\end{array}$ & Layak \\
\hline $\mathrm{Xi}-0,6 \mathrm{SBi}<\mathrm{X} \leq \mathrm{Xi}+0,6 \mathrm{SBi}$ & Cukup Layak \\
\hline $\mathrm{Xi}-1,8 \mathrm{SBi}<\mathrm{X} \leq \mathrm{Xi}-0,6 \mathrm{SBi}$ & Kurang Layak \\
\hline $\mathrm{X} \leq \mathrm{Xi}-1,8 \mathrm{SBi}$ & Tidak Layak \\
\hline
\end{tabular}

Rata-rata ideal (Xi) dan simpangan baku (SBi) diperoleh dengan perhitungan menggunakan rumus berikut:

$\mathrm{Xi}=1 / 2($ skor maksimal ideal + skor minimal $)$

Sbi $=(1 / 2)(1 / 3)($ skor maksimal ideal - skor minimal)

Data skor penilaian yang diperoleh juga dihitung dengan mengkonversi nilai kelayakan yang didapatkan menjadi skor dengan nilai skala 100 guna memberikan kemudahan dalam menyampaikan nilai hasil uji kelayakan. Dalam mengkonversi skor ke dalam nilai dengan skala 100 maka dipergunakan rumus konversi sebagai berikut:

$$
\mathrm{N}=\frac{(\mathrm{X}-\mathrm{XR})}{(\mathrm{XT}-\mathrm{XR})} \times 100
$$


Keterangan:

$\begin{array}{ll}\mathrm{N} & =\text { Nilai dalam skala } 100 \\ \mathrm{X} & =\text { Skor yang didapatkan dari penilaian } \\ \mathrm{XT} & =\text { Skor maksimal ideal } \\ \mathrm{XR} & =\text { Skor minimal }\end{array}$

\section{HASIL DAN PEMBAHASAN}

Hasil penelitian pada pengembangan media pembelajaran modul Mekanika Teknik ini dijelaskan sesuai dengan urutan pengembangan siklus 4D.

\section{Tahap Define}

Indikator keterlaksanaan tahap define diambil dari hasil analisis penilaian proses pengembangan yang telah dinilai oleh Dr. Drs. V. Lilik Hariyanto, M.Pd. Tahap define perolehan skor sebesar 40 berada pada rentang 37,8 < X sehingga masuk dalam kategori dilaksanakan dengan "sangat baik". Skor perolehan juga dikonversi ke dalam nilai skala 100 dengan hasil 86,11.

\section{a. Front-end analysis}

Dalam kegiatan ini peneliti telah melaksanakan observasi di SMK Negeri 1 Sedayu untuk menganalisis problematika yang muncul dalam kegiatan pembelajaran pada saat mata pelajaran Mekanika Teknik di kelas X. Hasil dari observasi tersebut peneliti menemukan adanya masalah dalam kegiatan pembelajaran khususnya pada mata pelajaran Mekanika Teknik yaitu sebagai berikut:

1) Belum digunakan modul yang secara khusus membahas tentang mata pelajaran Mekanika Teknik sebagai buku pegangan guru dalam mengajar dan siswa sebagai media pembelaran mandiri.

2) Materi pembelajaran direncanakan dan disusun secara mandiri oleh guru berdasarkan pengetahuan guru dan diambil dari berbagai referensi sehingga membuat guru menjadi sangat repot dalam mempersiapkan proses pembejaran.

3) Buku referensi terkadang meminjam dari jurusan lain seperti jurusan Teknik Pemesinan sehingga dikhawatirkan adanya ketidak-tepatkan materi terhadap program kompetensi keahlian Desain Permodelan dan Informasi Bangunan (DPIB).

\section{b. Leaner analysis}

Data yang diperoleh dari observasi karakteristik siswa adalah pada proses pembelajaran Mekanika Teknik berlangsung pengajar dalam hal ini guru dirasa sangat aktif dalam memberikan materi sedangkan peserta didik dalam hal ini siswa dirasa berperilaku pasif dengan sesekali mencatat materi yang diberikan oleh guru. Beberapa kali guru memberikan pertanyaan sebagai umpan balik kepada siswa ada beberapa yang dapat menjawab namun juga ada yang dijumpai siswa yang tidak fokus sehingga tidak dapat menjawab pertanyaan dari guru. c. Task analysis

Tugas-tugas pokok tersebut berpedoman pada pemilihan materi yang diperoleh berdasarkan kompetensi dasar yang digunakan sebagai pedoman pembelajaran yang sudah disesuaikan dengan Kurikulum 2013.

Tabel 7. Kompetensi dasar Modul Mekanika Teknik

\begin{tabular}{|c|c|c|c|}
\hline \multicolumn{2}{|c|}{$\begin{array}{l}\text { Kompetensi Dasar } \\
\text { (Pengetahuan) }\end{array}$} & \multicolumn{2}{|c|}{$\begin{array}{c}\text { Kompetensi Dasar } \\
\text { (Keterampilan) }\end{array}$} \\
\hline 3.1 & $\begin{array}{l}\text { Memahami } \\
\text { elemen-elemen } \\
\text { struktur. }\end{array}$ & 4.1 & $\begin{array}{l}\text { jikan } \\
\text { l-elemen } \\
\text { r }\end{array}$ \\
\hline 3.2 & $\begin{array}{l}\text { Memahami faktor } \\
\text { yang } \\
\text { mempengaruhi } \\
\text { struktur bangunan } \\
\text { berdasarkan } \\
\text { kriteria desain dan } \\
\text { pembebanan }\end{array}$ & 4.2 & $\begin{array}{l}\text { Menyajikan faktor } \\
\text { yang } \\
\text { mempengaruhi } \\
\text { struktur bangunan } \\
\text { berdasarkan } \\
\text { kriteria desain dan } \\
\text { pembebanan }\end{array}$ \\
\hline 3.3 & $\begin{array}{l}\text { Memahami } \\
\text { macam-macam }\end{array}$ & 4.3 & $\begin{array}{l}\text { Menyajikan } \\
\text { macam-macam }\end{array}$ \\
\hline
\end{tabular}




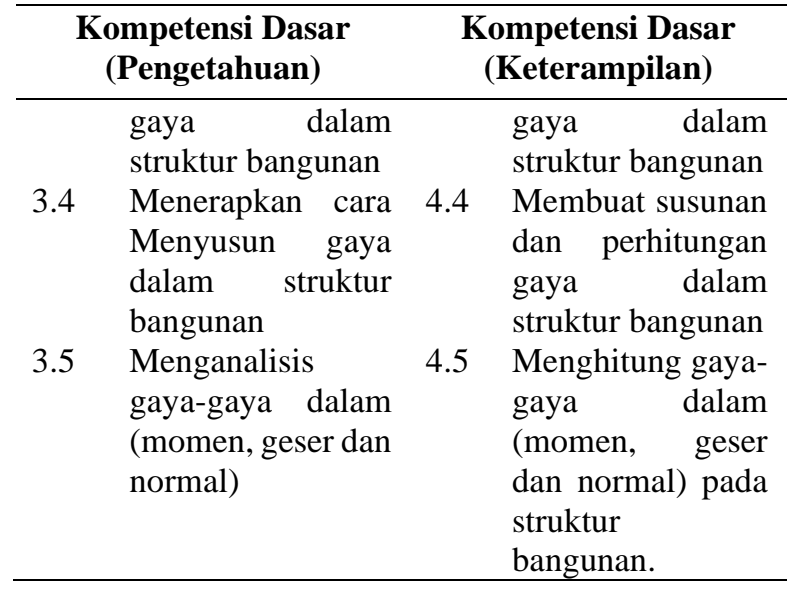

\section{d. Concept analysis}

Tabel 8. Pokok-Pokok Materi

\begin{tabular}{|c|c|}
\hline Pokok & Materi \\
\hline Pendahuluan & $\begin{array}{l}\text { Deskripsi, prasyarat, waktu, } \\
\text { petunjuk penggunaan modul, tujuan } \\
\text { akhir, dan standar kompetensi }\end{array}$ \\
\hline $\begin{array}{l}\text { KD } 3.1 \text { dan } \\
4.1\end{array}$ & $\begin{array}{l}\text { Struktur bangunan, klasifikasi } \\
\text { elemen struktur, elemen utama/ } \\
\text { tunggal struktur, satuan struktur } \\
\text { utama dan penggabungannya }\end{array}$ \\
\hline $\begin{array}{l}\text { KD } 3.2 \text { dan } \\
4.2\end{array}$ & $\begin{array}{l}\text { Faktor-faktor yang mempengaruhi } \\
\text { struktur, kriteria desain struktur, } \\
\text { kriteria pembebanan struktur, dan } \\
\text { kombinasi pembebanan }\end{array}$ \\
\hline $\begin{array}{l}\text { KD } 3.3 \text { dan } \\
4.3\end{array}$ & $\begin{array}{l}\text { Gaya internal pada struktur, proses } \\
\text { analisis gaya pada struktur, } \\
\text { fenomena struktur dasar, dan } \\
\text { pemodelan struktur }\end{array}$ \\
\hline $\begin{array}{l}\text { KD } 3.4 \text { dan } \\
4.4\end{array}$ & $\begin{array}{l}\text { Besaran, satuan, gaya, komposisi } \\
\text { gaya, menyusun gaya, menguraikan } \\
\text { gaya, dan hukum newton }\end{array}$ \\
\hline $\begin{array}{l}\text { KD } 3.5 \text { dan } \\
4.5\end{array}$ & $\begin{array}{l}\text { Tumpuan, jenis konstruksi, gaya } \\
\text { normal (normal forces diagram), } \\
\text { gaya lintang (shear force diagram), } \\
\text { momen (bending moment diagram, } \\
\text { dan menghitung gaya dalam (SFD, } \\
\text { NFD, dan BMD) }\end{array}$ \\
\hline
\end{tabular}

\section{e. $\quad$ Specifrying instructional objectives}

Pada kegiatan ini peneliti merumuskan tujuan pada modul pembelajaran yang diambil berdasarkan kompetensi dasar Mekanika Teknik pada kompetensi keahlian Desain Permodelan dan Informasi Bangunan.
1) Kompetensi dasar 3.1 dan 4.1

Siswa mampu mengidentifikasi elemen-elemen struktur utama pada bangunan secara tepat, mampu menjelaskan tentang elemen-elemen struktur pada bangunan dengan benar sesuai fungsinya, serta mempresentasikan tentang elemen elemen struktur dengan baik.

2) Kompetensi dasar 3.2 dan 4.2

Siswa mampu mengidentifikasi faktor-faktor yang mempengaruhi struktur pada bangunan secara tepat, mampu menjelaskan tentang faktor-faktor yang mempengaruhi struktur pada bangunan dengan benar, serta mampu mempresentasikan tentang faktor-faktor yang mempengaruhi struktur dengan baik.

3) Kompetensi dasar 3.3 dan 4.3

Siswa mampu mengidentifikasi macam-macam gaya dalam struktur bangunan secara tepat, mampu menjelaskan tentang macam-macam gaya dalam struktur bangunan dengan benar, serta mampu mempresentasikan tentang macam-macam gaya dalam struktur bangunan dengan baik.

4) Kompetensi dasar 3.4 dan 4.4

Siswa mampu mengidentifikasi cara menyusun gaya dalam struktur bangunan secara tepat, mampu menjelaskan tentang cara menyusun gaya dalam struktur bangunan dengan baik. mampu membuat susunan gaya dalam struktur bangunan dengan benar, serta mampu menghitung arah dan resultan gaya dalam struktur bangunan dengan benar.

5) Kompetensi dasar 3.5 dan 4.5

Siswa mampu mengidentifikasi macam-macam tumpuan pada struktur bangunan secara tepat, mampu mengidentifikasi jenis-jenis konstruksi struktur bangunan secara tepat, mampu mengidentikasi diagram gaya normal struktur bangunan secara tepat, mampu 
mengidentifikasi diagram gaya lintang struktur bangunan secara tepat, mampu mengidentifikasi diagram momen struktur bangunan secara tepat, serta mampu menghitung gaya-gaya dalam (momen, geser dan normal) pada struktur bangunan dengan benar.

\section{Tahap Design}

Indikator keterlaksanaan tahap design diambil dari hasil analisis penilaian proses pengembangan yang telah dinilai oleh Dr. Drs. V. Lilik Hariyanto, M.Pd. Tahap design perolehan skor maksimal sebesar 20 berada pada rentang $16,8<\mathrm{X}$ sehingga tahap perencanaan masuk dalam kategori dilaksanakan dengan "sangat baik". Skor perolehan juga dikonversi ke dalam nilai skala 100 dengan hasil 100.

\section{a. Construction criterion-referenced test}

Hasil dari tahap ini peneliti melakukan pemetaan kriteria dan mengklasifikasi kegiatan belajar sesuai pokok materi yang dibahas.

Tabel 9. Klasifikasi Kegiatan Pembelajaran pada Modul Mekanika Teknik

\begin{tabular}{|c|c|}
\hline $\begin{array}{c}\text { Pokok } \\
\text { pembahasan }\end{array}$ & $\begin{array}{c}\text { Klasifikasi kegaitan } \\
\text { pembelajaran }\end{array}$ \\
\hline Pendahuluan & Pendahuluan (BAB I) \\
\hline KD 3.1 dan 4.1 & $\begin{array}{l}\text { Kegiatan Belajar } 1 \text { (BAB II) } \\
\text { Elemen Struktur }\end{array}$ \\
\hline KD 3.2 dan 4.2 & $\begin{array}{l}\text { Kegiatan Belajar } 2 \text { (BAB III) } \\
\text { Faktor Desain dan Pembebanan } \\
\text { Struktur }\end{array}$ \\
\hline KD 3.3 dan 4.3 & $\begin{array}{l}\text { Kegiatan Belajar } 3 \text { (BAB IV) } \\
\text { Macam-Macam Gaya }\end{array}$ \\
\hline KD 3.4 dan 4.4 & $\begin{array}{l}\text { Kegiatan Belajar } 4 \text { (BAB V) } \\
\text { Menyusun Gaya }\end{array}$ \\
\hline KD 3.5 dan 4.5 & $\begin{array}{l}\text { Kegiatan Belajar } 5 \text { (BAB VI) } \\
\text { Gaya Normal, Gaya Lintang, } \\
\text { dan Momen }\end{array}$ \\
\hline
\end{tabular}

b. Media selection

Peneliti memilih media pembelajaran yang dirasa sangat tepat untuk dikembangkan ialah media pembelajaran modul yang sistematis, spesifik, interaktif dan mendetail pada setiap kompetensi dasarnya. Media pembelajaran modul dipilih dengan mempertimbangkan faktor efektifitas dan fakta biaya. Media pembelajaran modul diharapkan dapat dipakai siswa secara keseluruan sebagai buku pegangan agar dapat menunjang dalam proses pembelajaran Mekanika Teknik baik di dalam maupun di luar kelas secara mandiri.

c. Format selection

Tabel 10. Format Modul Pembelajaran

\begin{tabular}{l}
\hline HALAMAN SAMPUL \\
\hline KATA PENGANTAR \\
\hline DAFTAR ISI \\
\hline DARTAR GAMBAR \\
\hline DAFTAR TABEL \\
\hline PENDAHULUAN \\
\hline Deskripsi \\
Prasyarat \\
Waktu \\
Petunjuk Penggunaan Modul \\
Tujuan Akhir \\
$\quad$ Standar Kompetensi \\
\hline KEGIATAN BELAJAR 1-5 \\
\hline Kompetensi Dasar \\
Peta Konsep \\
Tujuan Pembelajaran \\
Uraian Materi \\
Rangkuman \\
Evaluasi \\
\hline DAFTAR PUSTAKA \\
\hline KUNCI JAWABAN
\end{tabular}

\section{d. Initial design}

Rancangan awal menghasilkan bentuk draf modul yang siap untuk diuji kelayakannya. Didalamnya sudah terdapat komponen-komponen penyusun modul mulai dari desain sampul, layout dan isi media.

Pada tahapan ini peneliti membuat suatu rancangan desain awal berupa desain sampul dan layout untuk media pembelajaran modul yang akan digunakan. Materi isi pada modul akan ditulis dengan bantuan Microsoft Word dan menggunakan ukuran kertas A4 $(21 \mathrm{~cm}$ x 29,2 cm) sesuai 
dengan standar penulisan media pembeajaran modul. Margin yang ditetapkan adalah $4 \mathrm{~cm}$ untuk bagian atas, $3 \mathrm{~cm}$ untuk bagian samping kanan, samping kiri dan bagian bawah. Isi naskah materi dari modul menggunakan jenis font arial dengan ukuran huruf 12 dan jarak 1,5 untuk mempermudahkan keterbacaan teks pada media pembelajaran modul.

\section{Tahap Development}

Indikator keterlaksanaan tahap development diambil dari hasil analisis penilaian proses pengembangan yang telah dinilai oleh Dr. Drs. V. Lilik Hariyanto, M.Pd. tahap development perolehan skor sebesar 19 berada pada rentang 16,8 $<\mathrm{X}$ sehingga tahap pengembangan masuk dalam kategori dilaksanakan dengan "sangat baik". Skor perolehan juga dikonversi ke dalam nilai skala 100 dengan hasil 93,75.

\section{a. Ekspert appraisal}

Validasi ahli dilakukan oleh ahli media, ahli materi, dan guru. Validasi dilakukan dengan memberikan berkasberkas validasi media pembelajaran Modul Mekanika Teknik kepada masing-masing validator. Hasil dari validasi berupa penilaian dan saran perbaikan media pembelajaran modul.

1) Validasi ahli media

Dari proses validasi ahli media yang dilakukan oleh expert di bidang media pembelajaran yaitu Ikhwanuddin, ST., MT., selaku dosen Pendidikan Teknik Sipil dan Perencanaan Fakultas Teknik Universitas Negeri Yogyakarta menghasilkan penilaian terhadap media pembelajaran modul dan komentar serta saran untuk perbaikan hingga media dinyatakan layak digunakan. Hasil dari penilaian menunjukan bahwa media pembelajaran modul Mekanika Teknik dinyatakan "layak digunakan dengan perbaikan”. Skor total penilaian dari ahli media secara komulatif dari 47 butir pertanyaan penilaian sebesar 222. Skor tersebut berapa pada rentang 197,4 < X sehingga masuk dalam kategori sangat layak. Hasil dari konversi skor perolehan ke dalam nilai skala 100 adalah sebesar 93,085.

Ada 3 aspek dalam penilailan media yaitu: (1) Aspek ukuran, (2) Aspek desain sampul, dan (3) Aspek desain isi. Pada aspek ukuran mendapatkan skor 5 berapa pada rentang 4,2 < X sehingga dinyatakan bahwa pada aspek ukuran media pembelajaran modul sudah sangat layak dan memiliki nilai konversi sebesar 100. Pada aspek desain sampul mendapatkan skor sebesar 62 dari 14 butir pertanyaan penilaian dan jika dikonversi akan mendapatkan nilai sebesar 85,71. Dari skor perolehan masuk pada rentang 58,8 $<\mathrm{X}$ sehingga aspek desain sampul pada media pembelajaran modul Mekanika Teknik nyatakan sangat layak. Pada aspek desain sampul ahli media memberikan saran tentang desain sampul yaitu ilustrasi jembatan yang sebelumnya kurang merepresentasikan tentang mata pelajaran Mekanika Teknik sehingga perlu diganti dengan ilustrasi yang sesuai.

Pada aspek desain isi mendapatkan skor sebesar 153 dari 32 butir pertanyaan penilaian dan jika dikonversi akan mendapatkan nilai sebesar 96,093. Skor perolehan tersebut masuk dalam rentang $134,4<X$ sehingga aspek desain isi pada media pembelajaran modul dinyatakan sangat layak. Dalam aspek desain isi ahli media memberikan saran berupa perbaikan widow dan orphan pada beberapa bagian di dalam media terkait. Ahli media juga memberikan masukan tentang konsistensi penanda paragraf baru sehingga peneliti perbaiki dengan menyesuaikan konsistensi penulisan naskah media pembelajaran modul Mekanika Teknik. 
2) Validasi ahli materi

Validasi ahli materi dilakukan oleh Ir. Pramudiyanto, S.Pd.T., M.Eng. selaku ahli di bidang materi tentang Mekanika Teknik dan merupakan dosen Pendidikan Teknik Sipil dan Perencanaan Fakultas Teknik Universitas Negeri Yogyakarta. Hasil dari validasi ahli materi dalam penelitian ini adalah berupa penilaian kelayakan materi dari media pembelajaran terkait yang dinilai oleh validator pada instrumen penilaian ahli materi. Ahli materi memberikan pernyataan bahwa media pembelajaran modul Mekanika Teknik dinyatakan "layak digunakan sebagai sumber belajar dengan revisi”. Skor total dari penilaian ahli materi secara komulatif dari 42 pertanyaan penilaian mendapatkan skor sebesar 163 berada pada rentang $142,8<\mathrm{X}<176,4$ sehingga dari ahli materi media pembelajaran modul Meknika Teknik dinyatakan "Layak". Hasil dari konversi skor perolehan ke dalam nilai skala 100 adalah sebesar 72,023.

Ada 7 aspek dalam penilaian ahli materi yaitu: (1) aspek cakupan materi, (2) aspek ketepatan materi, (3) aspek evaluasi, (4) aspek dimensi keterampilan, (5) aspek organisasi materi, (6) aspek pendukung penyajian materi, dan (7) aspek kelengkapan penyajian. Aspek cakupan materi masuk kategori layak dengan perolehan skor sebesar 24 dari 6 butir pertanyaan penilaian berapa pada rentang $20,4<X<25,2$ dan memiliki nilai konversi sebesar 75. Aspek ketepatan materi masuk kategori layak dengan perolehan skor sebesar 21 dari 6 butir pertanyaan penilaian berapa pada rentang 20,4 $<X<25,2$ dan memiliki nilai konversi sebesar 62,5. Aspek evaluasi masuk kategori layak dengan perolehan skor sebesar 20 dari 5 butir pertanyaan penilaian berapa pada rentang $17<\mathrm{X}<21$ dan memiliki nilai konversi sebesar 75. Aspek dimensi keterampilan masuk kategori layak dengan perolehan skor sebesar 16 dari 4 butir pertanyaan penilaian berapa pada rentang 13,6 $<X<16,8$ dan memiliki nilai konversi sebesar 75. Aspek organisasi materi masuk kategori layak dengan perolehan skor sebesar 33 dari 9 butir pertanyaan penilaian berapa pada rentang $30,6<\mathrm{X}<37,8$ dan memiliki nilai konversi sebesar 66,67. Aspek pendukung penyajian materi masuk kategori layak dengan perolehan skor sebesar 26 dari 7 butir pertanyaan penilaian berapa pada rentang 23,8 < X < 29,4 dan memiliki nilai konversi sebesar 67,85. Aspek kelengkapan penyajian masuk kategori sangat layak dengan perolehan skor sebesar 23 dari 5 butir pertanyaan penilaian berapa pada rentang 21 $<\mathrm{X}$ dan memiliki nilai konversi sebesar 90. Pada instrumen penilaian ahli materi tidak terdapat saran perbaikan secara spesifik dari validator sehingga peneliti berinisiatif untuk memperbaiki sendiri modul dengan memperhatikan skor pada butir soal yang paling rendah.

3) Validasi guru

Validasi Guru dilakukan dengan memberikan penilaian media pembelajaran modul Mekanika Teknik oleh Sidiq Subekti, S.Pd., selaku guru mata pelajaran Mekanika Teknik kompetensi keahlian Desain Permodelan dan Informasi Bangunan di SMK Negeri 1 Sedayu. Hasil dari penilaian guru adalah penilaian kelayakan media pembelajaran modul terkait serta komentar dan saran untuk perbaikan modul terkait. Pengguna memberikan pernyataan bahwa media pembelajaran modul Mekanika Teknik dinyatakan "layak digunakan sebagai sumber belajar dengan revisi". Skor total dari penilaian pengguna secara komulatif dari 42 pertanyaan penilaian 
mendapatkan skor sebesar 207 berada pada rentang $176,4<\mathrm{X}$ sehingga dari penilaian pengguna, media pembelajaran modul Meknika Teknik dinyatakan "sangat layak". Hasil dari konversi skor perolehan ke dalam nilai skala 100 adalah sebesar 98,21.

Validasi Guru terdiri dari 7 aspek penilaian yaitu: (1) aspek cakupan materi, (2) aspek ketepatan materi, (3) aspek evaluasi, (4) aspek dimensi keterampilan, (5) aspek organisasi materi, (6) aspek pendukung penyajian materi, dan (7) aspek kelengkapan penyajian. Aspek cakupan materi masuk kategori sangat layak dengan perolehan skor sebesar 30 dari 6 butir pertanyaan penilaian berapa pada rentang 25,2 < X dan memiliki nilai konversi sebesar 100. Aspek ketepatan materi masuk kategori sangat layak dengan perolehan skor sebesar 30 dari 6 butir pertanyaan penilaian berapa pada rentang $25,2<\mathrm{X}$ dan memiliki nilai konversi sebesar 100. Aspek evaluasi masuk kategori sangat layak dengan perolehan skor sebesar 25 dari 5 butir pertanyaan penilaian berapa pada rentang $21<\mathrm{X}$ dan memiliki nilai konversi sebesar 100. Pada aspek evaluasi validator pengguna memberikan masukan untuk memberikan evaluasi untuk mengukur keterampilan siswa sehingga peneliti menambahkan tugas tambahan untuk mengukur keterampilan siswa pada kegiatan belajar 1, kegiatan belajar 2, dan kegiatan belajar 3. Untuk kegiatan belajar 4 dan kegiatan belajar 5 dirasa sudah dapat mengukur keterampilan siswa dengan mengerjakan essay. Aspek dimensi keterampilan masuk kategori sangat layak dengan perolehan skor sebesar 18 dari 4 butir pertanyaan penilaian berapa pada rentang 16,8 < X dan memiliki nilai konversi sebesar 87,5. Aspek organisasi materi masuk kategori sangat layak dengan perolehan skor sebesar 44 dari 9 butir pertanyaan penilaian berapa pada rentang $37,8<\mathrm{X}$ dan memiliki nilai konversi sebesar 97,22. Aspek pendukung penyajian materi masuk kategori sangat layak dengan perolehan skor sebesar 35 dari 7 butir pertanyaan penilaian berapa pada rentang $29,4<X$ dan memiliki nilai konversi sebesar 100. Aspek kelengkapan penyajian masuk kategori sangat layak dengan perolehan skor sebesar 25 dari 5 butir pertanyaan penilaian berapa pada rentang $21<\mathrm{X}$ dan memiliki nilai konversi sebesar 100. Validator pengguna juga memberikan saran perbaikan tentang penulisan yang salah atau kekurangan huruf sehingga peneliti perlu memperbaiki.

\section{b. Development testing}

Uji coba pada tahap ini tidak dilakukan karena ada alasan-alasan tertentu. Alasan tersebut antara lain situasi dan kondisi yang tidak mendukung dilakukannya proses uji coba produk. Proses uji coba ini tidak karena situasi dan kondisi yang tidak memungkinkan yaitu adanya pandemi covid-19 sehingga proses kegiatan belajaran di sekolah terhambat.

\section{Tahap Disseminate}

Penyebaran media merupakan tahapan terakhir dalam penelitian pengembangan model 4D. Setelah modul selesai melalui proses validasi dan revisi produk sehingga media pembelajaran modul Mekanika Teknik dinyatakan layak digunakan, selanjutnya diserahkan kepada pengguna yaitu guru Mekanika Teknik kelas X Desain Permodelan dan Informasi Bangunan di SMK Negeri 1 Sedayu. Pendistribusian dilakukan secara online dengan mengirim softfile kepada guru mekanika teknik yang kemudian didistribusikan ke siswa.

Indikator keketerlaksanaan tahap disseminate diambil dari hasil analisis penilaian proses pengembangan yang telah dinilai oleh Dr. Drs. V. Lilik Hariyanto, 
M.Pd. Tahap disseminate perolehan skor sebesar 5 berada pada rentang 4,2 $<\mathrm{X}$ sehingga tahap pengembangan masuk dalam kategori dilaksanakan dengan "sangat baik". Skor perolehan juga dikonversi ke dalam nilai skala 100 dengan hasil 100.

\section{SIMPULAN}

Proses pengembangan model 4D pada media pembelajaran modul Mekanika Teknik ditinjau dari keterlaksanaan 4 tahapan yaitu meliputi: tahap pendefinisian (Define), tahap perencanaan (Design), tahap pengembangan (Development), dan tahap penyebaran produk (Disseminate). Penilaian proses pengembangan model 4D didapatkan skor sebesar 84 berada pada rentang 75,6 < $\mathrm{X}$ dengan masuk dalam kategori "Sangat Baik". Skor perolehan juga dikonversi ke dalam nilai skala 100 dengan hasil 91,66.

Tahap define menghasilkan simpulan sebagai berikut: (1) Analisa awal, belum tersedianya media pembelajaran modul yang spesifik membahas mata pelajaran Mekanika Teknik. (2) Analisis siswa, peseta didik cukup pasif dalam kegiatan pembelajaran teori di dalam kelas. (3) Analisis tugas, tugas yang dibuat dalam modul disesuaikan dengan kompetensi dasar sesuai dengan kurikulum 2013 revisi. (4) Analisis konsep, penyajian materi dalam media pembelajaran modul merupakan pengembangan dari kompetensi dasar dan menghasilkan pokok-pokok materi. (5) Spesifikasi objek instruksional, tujuan pembelajaran yang dirumuskan menyesuaikan dengan kompetensi dasar yang digunakan sebagai pedoman pembelajaran. Tahap define dilaksanakan dengan sangat baik didapatkan skor 40 berada pada rentang $37,8<\mathrm{X}$. Skor perolehan juga dikonversi ke dalam nilai skala 100 dengan hasil 86,11.

Tahap design menghasilkan simpulan sebagai berikut: (1) Penyusunan kriteria, peneliti melakukan observasi dan berdiskusi bersama guru mata pelajaran Mekanika Teknik tentang pengembangan media pembelajaran. (2) Pemilihan media, peneliti memilih media pembelajaran modul sebagai media yang dikembangkan. (3) Pemilihan format, peniliti menentukan format untuk media pembelajaran modul agar memudahkan dalam penggunaan media pembelajaran modul Mekanika Teknik (4) Rancangan awal, peneliti membuat layout untuk modul yang akan digunakan dan mendesain modul baik desain sampul, header footer, dan layout naskah isi modul. Tahap design dilaksanakan dengan sangat baik didapatkan skor maksimal 20 berada pada rentang $16,8<\mathrm{X}$. Skor perolehan juga dikonversi ke dalam nilai skala 100 dengan hasil 100.

Tahap development menghasilkan simpulan sebagai berikut: (1) Validasi ahli media menghasilkan penilaian dari 3 aspek kelayakan media yaitu aspek ukuran, aspek desain sampul, dan aspek desain isi. Penilaian validasi dari ahli media didapatkan skor sebesar 222 berada pada rentang 197,4 $<\mathrm{X}$ dengan masuk dalam kategori "Sangat Layak" dan memiliki nilai konversi sebesar 93,085. Validator ahli media memberikan masukan berupa saran untuk memperbaiki ilustrasi pada sampul, konsistensi penanda paragraf baru, widow dan orphan. (2) Validasi ahli materi menghasilkan penilaian dari 7 aspek kelayakan materi pada media pembelajaran modul yaitu apek cakupan materi, aspek ketepatan materi, aspek evaluasi, aspek dimensi keterampilan, aspek organisasi materi, aspek pendukung penyajian materi dan aspek kelengkapan 
penyajian. Penilaian validasi dari ahli materi didapatkan skor sebesar 163 berada pada rentang 142,8 $<X \leq 176,4$ dengan masuk dalam kategori "Layak" dan memiliki nilai konversi sebesar 72,023. (3) Validasi guru menghasilkan penilaian dari 7 aspek penilaian bagi pengguna pada media pembelajaran modul yaitu apek cakupan materi, aspek ketepatan materi, aspek evaluasi, aspek dimensi keterampilan, aspek organisasi materi, aspek pendukung penyajian materi dan aspek kelengkapan penyajian. Penilaian validasi dari pengguna didapatkan skor sebesar 207 berada pada rentang 176,4 < X dengan masuk dalam kategori "Sangat layak" dan memiliki nilai konversi sebesar 98,21. Guru memberikan masukan berupa saran untuk memperbaiki kesalahan penulisan pada modul dan penyesuaian evalusai dengan tujuan pembelajaran. Tahap development dilaksanakan dengan sangat baik didapatkan skor 19 berada pada rentang 16,8<X. Skor perolehan juga dikonversi ke dalam nilai skala 100 dengan hasil 93,75.

Tahap disseminate menghasilkan simpulan sebagai berikut: Peneliti melakukan penyebaran modul kepada guru mata pelajaran Mekanika Teknik di SMK Negeri 1 Sedayu. Tahap disseminate dilaksanakan dengan sangat baik didapatkan skor 5 berada pada rentang 4,2 < X dan nilai konversi sebesar 100.

\section{DAFTAR RUJUKAN}

Badan Pusat Statistik. (2020). Februari 2020: Tingkat Pengangguran Terbuka. Jakarta: Badan Pusat Statistik.

Daryanto. (2013). Menyusun Modul Bahan Ajar Untuk Persiapan Guru dalam Mengajar. Yogyakarta: Gava Media.
Nurseto, T. (2011). Membuat Media Pembelajaran yang Baik. Jurnal Ekonomi \& Pendidikan, Volume 8, Nomor 1.

Pebrianto, F. (2020). Tingkat Pengangguran Terbuka Per Februari 2020. Jakarta: Tempo.com.

Sanaky, H.A.H. (2013). Media Pembelajaran Interaktif-Inovatif. Yogyakarta: Kaukaba Dipantara.

Saputro, A. (2015). Pengembangan Modul Pembelajaran Autocad Untuk Mata Pelajaran Gambar Teknik Siswa Kelas X Jurusan Teknik Ketenagalistrikan SMKN 2 Pengasih Yogyakarta. Skripsi. FT-UNY.

Sugiyono. (2015). Metode Penelitian dan Pengembangan Research and Development. Bandung: Alfabeta.

Thiagarajan, S: Semmel, D. S \& Semmel, M. I. (1974). Development for Training Teachers of Exeptional Children: a Sourcebook. Indiana: Indiana University.

Tim Penyusun Tugas Akhir. (2016). Pedoman Tugas Akhir UNY. Yogyakarta: Universitas Negeri Yogyakarta.

Sumardjo, S., Pratama, G. N. I. P., \& Vemantyasto, T. N. (2020). Efektivitas Modul Estimasi Biaya Konstruksi Jalan pada Mata Pelajaran Estimasi Biaya Konstruksi Di SMK N 1 Purworejo. Jurnal Pendidikan Teknik Sipil,2(2), 104116. 